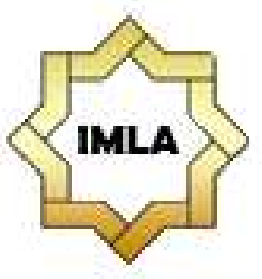

\author{
Al-Ta'rib \\ Jurnal Ilmiah Program Studi Pendidikan Bahasa Arab \\ IAIN Palangka Raya \\ Vol. 9, No. 2, December 2021, 133-144 \\ p-ISSN 2354-5887 | e-ISSN 2655-5867 \\ DOI: https://doi.org/10.23971/altarib.v9i2.3043
}

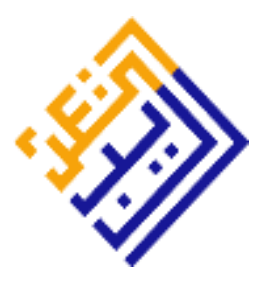

\title{
ANALYZING ERRORS IN LESSON PLANS OF ARABIC TEACHER PROFESSIONAL EDUCATION PARTICIPANTS DURING THE TEACHING PRACTISE AT SCHOOLS
}

\author{
Moh. Ainin', Mohammad Ahsanuddin'2, Irhamni' ${ }^{3}$, Muhammad Lukman \\ Arifianto $^{4}$, Moch. Wahib Dariyadi ${ }^{5}$, Faishol Mahmud Adam Ibrahim ${ }^{6}$ \\ 1,2,3,4,5 Universitas Negeri Malang, Indonesia \\ 6University of the Holy Quran and Islamic Sciences, Sudan \\ E-mail:moh.ainin.fs@um.ac.id
}

\begin{abstract}
One of the government's efforts to improve the quality and professionalism of teachers, especially Arabic teachers, is the implementation of an in-service Teacher Professional Education Program (Pendidikan Profesi Guru - PPG). During the program, teachers also learn to develop lesson plans (Rencana Pelaksanaan Pembelajaran - RPP). Errors were reported in the lesson plans prepared by teachers of Arabic Language as PPG participants during the teaching practice at schools. Therefore, the purpose of this study was to describe those errors. By using a descriptive-qualitative design, this study revealed eight types of errors in the lesson plans, namely (1) ambiguity in the basic competence formulation, (2) GPA formulation that focused more on the process and not competence, (3) invalidity of the assessment instrument, (4) unspecific, non-operational, and unmeasurable formulation of GPA, (5) GPA formulation asynchronous with teaching and learning activities, (6) unclear formulation of teaching and learning activities, (7) unclear measurement of competence, and (8) domain misconceptions in the assessment.
\end{abstract}

Keywords: lesson plan error, in-service PPG participants, Arabic teaching practice

\section{Abstrak}

Salah satu upaya pemerintah untuk meningkatkan kualitas dan profesionalitas guru, khususnya guru bahasa Arab adalah penyelenggaraan Program Pendidikan Profesi Guru (PPG) dalam jabatan. Di antara materi PPG tersebut adalah pengembangan perencanaan pembelajaran (penyusunan RPP). Di tengarahi, bahwa terdapat kesalahan dalam RPP yang disusun oleh peserta PPG dalam jabatan matapelajaran Bahasa Arab saat praktik mengajar di sekolah. Tujuan penelitian ini adalah mendeskripsikan kesalahan RPP yang digunakan oleh mereka saat praktik mengajar. Penelitian ini menggunakan desain deskriptif-kualitatif. Hasil penelitian menunjukkan bahwa ada delapan tipe kesalahan yang terdapat pada RPP, yaitu (1) ketaksaan dalam perumusan Kompetensi Dasar (KD), (2) rumusan Indikator Pencapaian Keberhasilan (IPK) lebih menggambarkan proses, bukan kompetensi, (3) ketidakvalidan instrumen penilaian, (4) rumusan IPK tidak 
spesifik, operasional, dan tidak terukur, (5) ketidaksinkronan antara rumusan IPK dan kegiatan belajar mengajar, (6) ketidakjelasan rumusan kegiatan belajar mengajar, (7) ketidakjelasan kompetensi yang diukur, dan (8) miskonsepsi penempatan ranah (domain) dalam penilaian.

Kata kunci: Kesalahan RPP, Peserta PPG dalam jabatan, dan Praktik mengajar Bahasa Arab

\section{INTRODUCTION}

According to Cooper, teachers or educators as decision-makers in the learning process have three main tasks: planning, implementation, and evaluation (Cooper, 1977). One manifestation in the planning stage is preparing lesson plans (Rencana Pelaksanaan Pembelajaran - RPP). In preparing the lesson plans, teachers carried out several operational tasks, including analyzing student needs, formulating learning objectives, determining learning models and strategies to achieve goals, and preparing teaching materials. The plans above guide teachers in carrying out the learning process (Abidin, 2014).

Implementation comes after planning. Implementation is the realization of planning. Then, teachers have to assess the learning system implemented related to learning processes and outcomes in various ways and with multiple instruments-it is known as the evaluation process. The following chart illustrates the three main tasks of teachers from Cooper.

\section{Chart 1: The three main tasks of teachers}

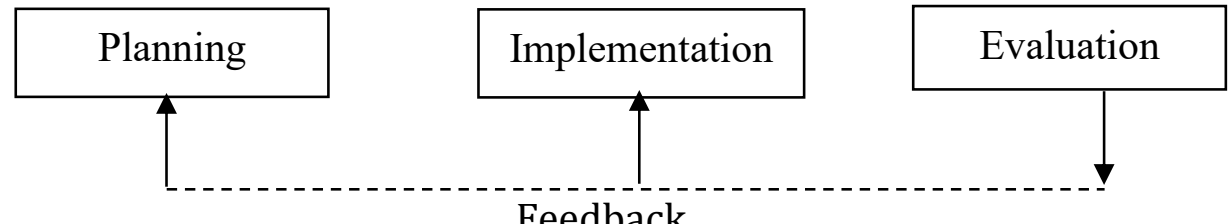

Feedback

Government Regulation Number 74 of 2008 concerning Teachers states that teachers must have characters, social skills, and pedagogic and professional competence (Peraturan Pemerintah No. 74 Tahun 2008 tentang Guru, 2008). Among the pedagogic and professional competence is the ability to develop a curriculum related to their expertise and planning and implementing learning processes (Mahsunah dkk., 2012). The concrete form of curriculum development is syllabus and lesson plans. If the curriculum is normative, then the lesson plan has an operational-applicative design. The lesson plans used as a guiding tool for operational-applicative teachers must be complete, systematic, easy to apply, but still flexible and accountable (Abidin, 2014).

One of the efforts done by the Ministry of Education to improve the quality and professionalism of teachers, especially Arabic teachers, is the implementation of the in-service Teacher Professional Education Program (Pendidikan Profesi Guru or PPG) (Kementerian Pendidikan dan Kebudayaan, 2017). This program also intends to increase the teachers' contribution to accelerating Indonesia's golden generation in 2045. PPG refers to Government Regulation Number 19 of 2017 (referred to the changes of Government Regulation Number 74 of 2008)

\footnotetext{
Jurnal Ilmiah Program Studi Pendidikan Bahasa Arab IAIN Palangka Raya Vol. 9, No. 2 /133-144
} Al-Ta'rib | p-ISSN 2354-5887 | e-ISSN 2655-5867 
Article 66 paragraph (1) concerning Teachers, which says that in-service teachers who have not obtained the Educator Certificate must join PPG.

The Arabic Language Education Study Program, Department of Arabic Literature, Faculty of Letters, Universitas Negeri Malang has been trusted by the Ministry of Education to organize the in-service PPG Program for teachers of the Arabic language subject. One indicator of professionalism is the competence in making lesson plans, which later will be implemented in Field Experience Activities (Kegiatan Pengalaman Lapangan - KPL). Considering the importance of lesson planning, PPG allocates 18 hours for lesson planning. However, the supervising lecturers found some errors in lesson plans in KPL at schools. The errors refer to deviations in formulating lesson plan components and inconsistency between components in the developed lesson plans.

The condition shall not be tolerated because it is contradictory to the goal of PPG to produce competent teachers. The errors found also illustrated the lack of competence among teachers as mandated in Law Number 14 of 2005 on Teachers and Lecturers (Undang-Undang Republik Indonesia Nomor 14 Tahun 2005 tentang Guru dan Dosen, 2005). Teachers or educators must develop professional competence indicated by the ability to prepare lesson plans (Mahsunah dkk., 2012). Preparing lesson plans is one of a teacher's primary tasks before carrying out the learning and assessment process (Cooper, 1977).

Lesson plans are the central part of an effective learning system used to improve the quality of learning. Several studies have proved the effectiveness of lesson plans for learning. Dorovolomo showed a positive relationship between the quality of lesson plans and delivery of teaching materials-this finding reinforces the idea that teachers learn to make lesson plans in teacher education (Dorovolomo dkk., 2010). Cicek and Tok conducted a comparative study between lesson plans in the US and Turkish schools. They discovered that each country's content of lesson plans was almost the same, and incorporating the C-Scope program could help teachers be more effective in preparing lesson plans. C-Scope itself is a curriculum support system program that provides annual and daily lesson plans as a whole. With C-Scope, preparing lesson plans will not consume much time. Any variations or designs of lesson plans have a role for teachers in the teaching and learning process (Cicek \& Tok, 2014). Syahrir pointed out that the quality of learning tools (lesson plans) could enhance students' creative thinking effectively (Syahrir, 2016).

Related to the problems above, the purpose of this study is to describe the errors in the lesson plans prepared by in-service Arabic PPG participants. This study discussed lesson plan errors systematically, objectively, and holistically based on empirical data. The results of this study are expected to provide benefits, both theoretically and practically. Theoretically, this study provides comprehensive information on errors in the lesson plans prepared by in-service Arabic PPG participants. Whereas, practically, this study helps to show the benefits of increasing the ability of PPG participants and Arabic teachers in general in preparing good and correct Arabic lesson plans. 


\section{METHOD}

Following the research objective, this study used a descriptive-qualitative design. As a qualitative research, this research describes the data as it is holistically and inductively-deductively (Creswell, 2014). The data was in the form errors found in those lesson plans developed by in-service PPG participants during the teaching practice at schools. There were 26 lesson plans analyzed. As a qualitative research, the main instrument in this study was a human instrument (Sugiyono, 2018). There was also an auxiliary instrument in the form of an analysis guide. Data were analyzed using techniques from Corder (in Ellis), which included (a) error selection, (b) errors in corpus identification, (c) error classification, (d) error explanation, and (e) conclusion (Ellis, 2020).

\section{RESULTS}

Based on the results of the data analysis, this study identified several errors in lesson plans developed by in-service PPG participants, as presented in this following section.

\section{Ambiguity in Formulating Basic Competence}

The ambiguity refers to the vague formulation of competence that describes Arabic skills such as listening, speaking, reading, or writing. One example of ambiguous basic competence formulation is presented below.

\begin{tabular}{|c|c|}
\hline Incorrect Formulation (Column A) & Reconstruction (Column B) \\
\hline $\begin{array}{l}\text { Showing a public building (al-mabna al- } \\
\text { amah) that is close to the daily lives of } \\
\text { students by paying attention to social } \\
\text { functions, text structures, and linguistic } \\
\text { elements in spoken and written } \\
\text { transactional interaction texts } \\
\text { according to the context }\end{array}$ & $\begin{array}{l}\text { Delivering information about the public } \\
\text { building (al-mabna al-amah) orally or in } \\
\text { writing that is close to the daily lives of } \\
\text { students by paying attention to social } \\
\text { functions, text structures, and linguistic } \\
\text { elements in spoken and written } \\
\text { transactional interaction texts according } \\
\text { to the context }\end{array}$ \\
\hline
\end{tabular}

The error in the formulation above is in using the behavioural phrase "showing a public building". This phrase does not illustrate the Arabic competence expected in the learning process, and it does not describe the expected learning outcomes. The phrase "showing a public building" may indicate the ability to show a building physically. By looking at the formulation context, the basic competence in column A can be reconstructed into "delivering information about the public building", which means that students must give information orally or in writing related to a public building.

\section{GPA Formulation Focuses on Process and Not on Competence}

The GPA formulation focused more on the learning activities or learning processes and not on the competence or learning outcomes, as presented below.

\begin{tabular}{|c|c|}
\hline Incorrect Formulation (Column A) & Reconstruction (Column B) \\
\hline $\begin{array}{l}\text { Observing and identifying the form and } \\
\text { theme about al mabaani al ammah text }\end{array}$ & $\begin{array}{l}\text { Explaining the form of al mabaani al } \\
\text { ammah text discourse correctly }\end{array}$ \\
\hline
\end{tabular}


correctly

The GPA formulation in column A was intended for knowledge, not skills. In other words, it does not describe the expected knowledge competence. The phrase "observing and identifying" depicts more on the learning process than on the expected learning outcomes. Meanwhile, a GPA formulation must represent learning outcomes and not the learning process. Through a complete evaluation of the lesson plans, the GPA formulation in column A can be reconstructed to be "explaining the form of al mabaani al ammah text discourse correctly", as in column B.

\section{Invalidity of the Assessment Instrument}

One of the characteristics of a good assessment instrument is validity. It means that an assessment or a test must measure what it is intended to measure. In the lesson plans compiled by in-service PPG participants, the assessment instrument did not measure what had to be measured. The example is presented below.

\begin{tabular}{ll}
\hline \multicolumn{1}{c}{ Incorrect Formulation (Column A) } & \multicolumn{1}{c}{ Reconstruction (Column B) } \\
\hline The test to determine the GPA of & The test is for verbal performance \\
students' speaking skills (ability to & (monologue or dialogue) related to self- \\
introduce, apologize, and say goodbye & introduction, saying thank you, and \\
correctly) about ta'aruf is in the form of & saying goodbye. \\
"multiple choice and gap-filling". & \\
\hline
\end{tabular}

The error in column $\mathrm{A}$ is in the assessment tool that uses multiple-choice and gap-filling, while the learning objective is to test students' speaking skills within the theme of ta'aruf or self-introduction. In this case, students are expected to introduce themselves, apologize, and say goodbye correctly. Therefore, the instrument mentioned above is invalid because multiple-choice or gap-filling tests cannot measure speaking skills. The test is supposed to be in verbal language performance related to self-introduction and saying thank you and goodbye in dialogue or monologue. The formulation in column A can be reconstructed as in column B, stating that "the test is for verbal performance (monologue or dialogue) related to self-introduction, saying thank you, and saying goodbye.".

Unspecific, Non-Operational, and Unmeasurable GPA Formulation

A suitable GPA formulation describes specific, operational, and measurable abilities. It was found that the GPA formulation was still general, not specific, not operational, and could not be measured. Here is an example of the wrong GPA formulation.

\begin{tabular}{lll}
\hline \multicolumn{2}{c}{ Incorrect Formulation (Column A) } & \multicolumn{1}{c}{ Reconstruction (Column B) } \\
\hline $\begin{array}{l}\text { Getting information about public } \\
\text { buildings }\end{array}$ & 1. Finding information explicitly in the \\
& $\begin{array}{l}\text { text about public buildings } \\
\text { 2. } \begin{array}{l}\text { Discovering information implicitly in } \\
\text { the text about public buildings } \\
\end{array} \\
\end{array}$ \\
$\begin{array}{l}\text { 3. } \\
\text { Re-explaining the content of a text } \\
\text { about public buildings }\end{array}$ \\
\hline
\end{tabular}


4. Summarizing the content of a text about public buildings

The GPA formulation in column A is still general in terms of competence and substance. In terms of competence, the formulation of "getting information" does not describe specific and operational competencies, so it cannot be measured. The limit of "getting information" is also unclear. Similarly, in terms of substance, "getting information" does not describe a competence or skill, whether related to listening or reading skills or both. By looking at the overall content of the lesson plans, the formula in column A can be reconstructed as in column B, saying that "1) finding explicit information in the text about public buildings, 2) discovering implicit information in the text about public buildings, 3 ) re-explaining the content of a text about public buildings, 4) summarizing the content of a text about public buildings, and 5) so on".

\section{GPA Formulation Not Synchronous with Teaching and Learning Activities}

One of the principles in preparing lesson plans is the synchronization between components. In the lesson plans developed by in-service Arabic PPG participants, there was an incompatibility between the GPA formulation and the teaching and learning activities. The example is as follows:

\begin{tabular}{lrl}
\hline \multicolumn{1}{c}{ Incorrect Formulation (Column A) } & Reconstruction (Column B) \\
\hline $\begin{array}{l}\text { GPA: Students are able to express } \\
\text { opinions verbally about the location of } \\
\text { public buildings. }\end{array}$ & $\begin{array}{l}\text { GPA: Students are able to speak orally } \\
\text { about the location of public } \\
\text { buildings in their schools. }\end{array}$ \\
$\begin{array}{l}\text { Core Teaching and Learning Activities: } \\
\text { Each student writes five (5) simple } \\
\text { sentences in Arabic related to the }\end{array}$ & $\begin{array}{l}\text { Teaching and Learning Activities: } \\
\text { (example) }\end{array}$ \\
$\begin{array}{l}\text { The } \\
\text { location of public buildings around the } \\
\text { school by using place information on a } \\
\text { piece of paper }\end{array}$ & $\begin{array}{l}\text { students orally about the location of } \\
\text { public buildings in the school, and } \\
\text { students answer orally. } \\
\text { Students orally tell the location of } \\
\text { public buildings in their school. }\end{array}$ \\
& $\begin{array}{l}\text { 3tudents make a dialogue (question } \\
\text { and answer) about the location of } \\
\text { public buildings in their school. }\end{array}$ \\
\hline
\end{tabular}

The data in column A shows that GPA formulation and the teaching and learning activities are not synchronous. The GPA formulation describes the ability to speak (Mahärah kaläm), while the core teaching and learning activities talk about writing activities. Therefore, the formulation in column $A$ can be reconstructed as in column $B$, which focuses on speaking skills. For example, the teacher asks students about the location of public buildings in the school, explain orally, do question and answer (dialogue) with their friends about the location of public buildings in their schools, and so on. 


\section{Unclear Formulation of Teaching and Learning Activities}

Good teaching and learning activities portray clear, concrete, and specific learning activities for the learners and the teachers. Ambiguity was found in the formulation of teaching and learning activities, as presented in the column below.

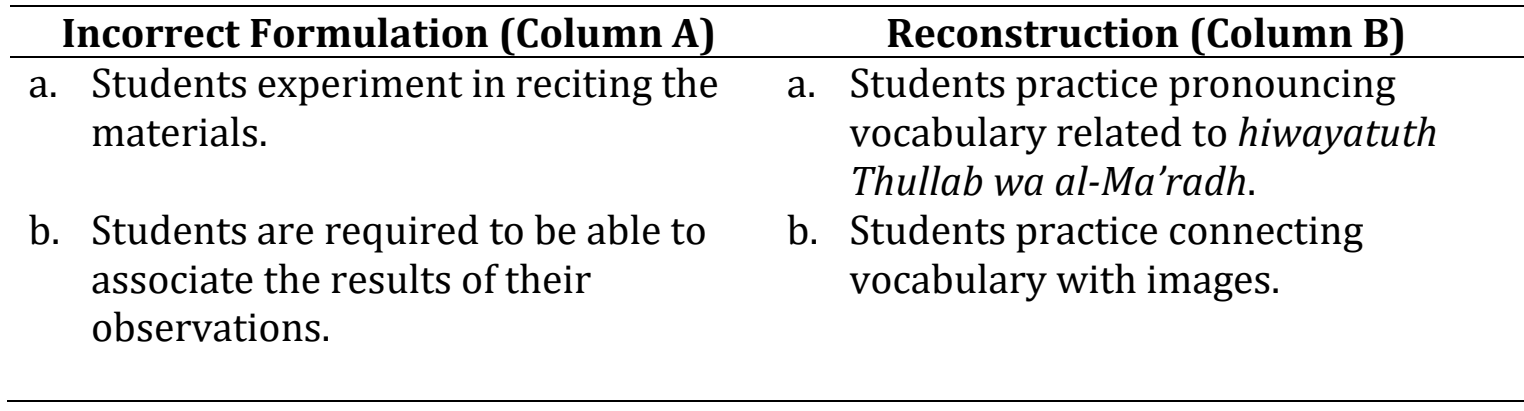

The data in column A shows that the teaching and learning activities are ambiguous. The use of the verb "experiment" before "reciting the materials" in point (a) is less collocative. Likewise, the formulation in point (b) that "students are required to be able to associate the results of their observations" is also unclear because it does not describe actual learning activities. The formulation in column A can be reconstructed as in column B. Teachers can let (a) students practice pronouncing vocabulary related to hiwayatuth Thullab wa al-Ma'radh and (b) students practice connecting vocabulary with images. The teaching and learning activities in column B are more concrete, clear, and specific.

\section{Unclear Measurement of Competence}

As explained in the previous section, one characteristic of a good assessment instrument is a valid measurement. A test validity means the clarity of the competence being measured. It was found that the lesson plans developed by in-service Arabic PPG participants had unclear competence measurement. The column below gives an example of an unclear measurement of competence.

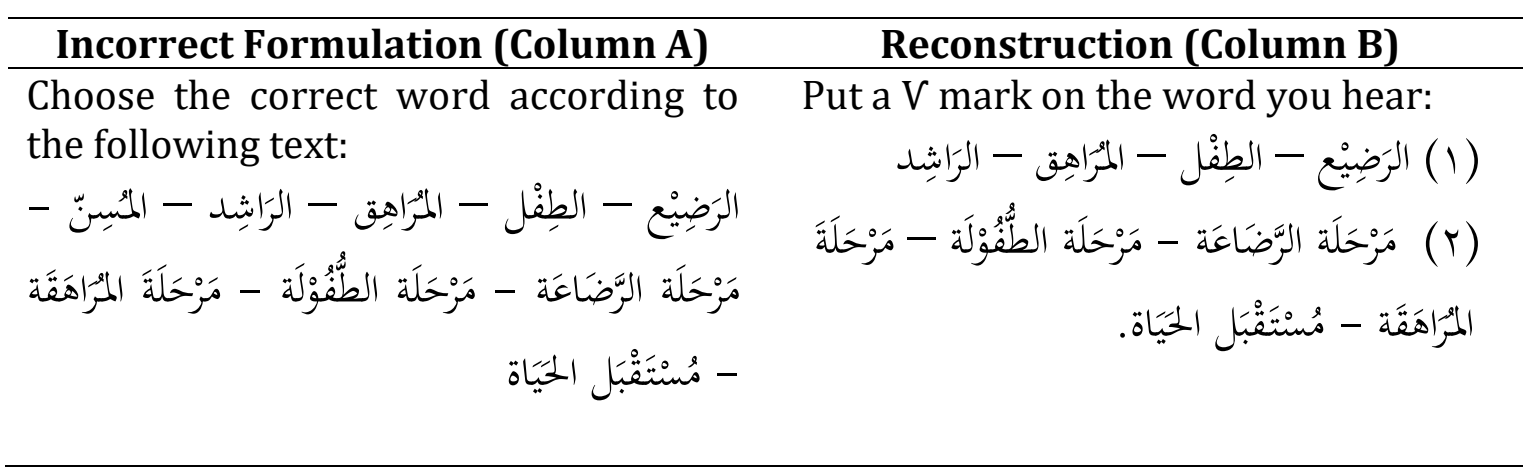

In terms of context, the instrument in column (A) is intended to measure students' basic listening skills. Column (A) requires students to match the vocabulary heard with the vocabulary written in the exercise sheet. However, the command does not describe the measurement clearly. The formulation of the 
questions or practice in column A should be changed. The formulation in column B signifies the ability being measured in the lesson plans to match the vocabulary heard with the vocabulary written on the exercise sheet.

\section{Domain Misconceptions in the Assessment}

The domain in learning Arabic includes knowledge and skills. Knowledge refers to, for example, understanding Arabic grammar, Arabic vocabulary, and Arabic sounds. Meanwhile, skills include listening, speaking, reading, and writing Arabic. There is a misconception on the domain assessed. The following column is an example of the misconception:

\begin{tabular}{ll}
\hline \multicolumn{1}{c}{ Incorrect Formulation (Column A) } & \multicolumn{1}{c}{ Reconstruction (Column B) } \\
\hline Assessment instrument: & Knowledge test: knowledge of Arabic \\
Knowledge test (multiple choice and & $\begin{array}{l}\text { grammar in the form of multiple- } \\
\text { choice and gap-filling (e.g. } \\
\text { gap-filling) } \\
\end{array}$ \\
& $\begin{array}{l}\text { determining mibtada-khabar from } \\
\text { text). }\end{array}$ \\
\hline
\end{tabular}

The formulation in column $\mathrm{A}$ is intended to measure the ability of the knowledge domain. The instrument developed is a multiple-choice and gap-filling test. The in-service Arabic PPG participants thought that multiple-choice and gapfilling tests were used to measure students' knowledge. It is a misconception because the multiple-choice and gap-filling test is used to measure knowledge and measure reading and listening skills. Multiple choice and gap-filling tests can measure students' knowledge when the competence being measured is in the dominant category of knowledge, such as grammar and vocabulary-for example, measuring the understanding of word structure in sentences. If this is the case, then the formulation in column A can be reconstructed as in column B.

\section{DISCUSSION}

The results show that errors in the lesson plans developed by in-service Arabic PPG participants during the teaching practice at schools varied. The errors included (1) ambiguity in the basic competence formulation, (2) GPA formulation that focused more on the process and not competence, (3) invalidity of the assessment instrument, (4) unspecific, non-operational, and unmeasurable formulation of GPA, (5) GPA formulation asynchronous with teaching and learning activities, (6) unclear formulation of teaching and learning activities, (7) unclear measurement of competence, and (8) domain misconceptions in the assessment.

The errors found in the lesson plans mostly were unclear narrative. The lack of clarity in planning has led to ambiguity in learning orientation, contents, inclass learning activities, and competence assessed. The implication is that the learning outcomes cannot be known. The preparation of the lesson plans ignored one of the principles in the Regulation of Minister of Education and Culture Number 65 of 2013, which emphasized the linkage and integration between basic competence, learning materials, learning activities, GPA, assessment, and learning resources in one learning experience (Abidin, 2014). 
Another prominent type of error was the ambiguity of GPA formulation. GPA is a description of basic competence whose formulation must use operational and specific verbs showing measurable traits. Based on the findings, the GPA formulation in the lesson plans was quite general (did not describe specific competence). It has made the learning outcomes difficult to measure. For example, using "understand" and "know" shall not be included in GPA formulation but rather on basic competence. In addition, the words "understand" and "know" cannot be measured in terms of achievement because they are not operational. Marzuqi also questioned the limits of "knowing", whether it is "understanding" or "perceiving" (Marzuqi, 1996). Therefore, Marzuqi stated that the verb "to know" has no boundaries and cannot be used to measure achievement (Marzuqi, 1996).

The problem in preparing lesson plans was related to assessing instrument development-ambiguity in describing competence and misconceptions about the measured domain. Due to this matter, the learning outcomes set became unclear. A learning outcome-based education system provides certainty for students to acquire knowledge, competence, and quality after graduating (Spady, 1994). If the lesson plans developed do not describe the learning outcomes, the learning outcomes are also unclear. In the perspective of the assessment theory, this error indicates the invalidity of a test because it does not measure the competence that should be measured (Santrock, 2010). Isn't that one of the proper test characteristics is how far the test or the evaluation instrument development measures abilities or skills that were supposed to be measured (Nurgiyantoro, 2016).

The ambiguity of the lesson plans has implications on the unclear learning outcomes and the quality of learning. (Dorovolomo dkk., 2010) revealed a significant relationship between the quality of planning and implementation in a learning process. By citing the opinion of Wilkerson and Scheffler, Dorovolomo et al. suggested that teacher education needed to be continuously developed, especially those related to the planning and implementation of learning (Dorovolomo dkk., 2010; Wilkerson \& Scheffler, t.t.). Cicek and Tok asserted that lesson plans influenced both learning and classroom management (Cicek \& Tok, 2014). Syahrir also underlined that the quality of learning tools (lesson plans) was effective for improving students' creative thinking (Syahrir, 2016).

From the previous research above, it can be stated that lesson plans are one of the most essential and functional components in the learning system. An applicative learning plan, or lesson plans, is a guiding tool for teachers (educators) in carrying out the learning process (Abidin, 2014). If the reference used as a learning guide is incorrect, the implementation of learning and the assessment system may also be not optimal. Even more, the direction of learning outcomes also becomes unclear.

Cooper regarded planning as the primary activity in the learning system (Cooper, 1977). Due to the functional and strategic position of the planning, the PPG Program allocates 18 hours to focus on the preparation of learning materials, one of which is developing lesson plans. It means that preparing lesson plans is a prerequisite that must be met as professional teachers (Gafur, 1982). 
The problem is that the in-service Arabic PPG participants seem to have not been able to adopt examples of lesson plans from exact sciences subjects. For this reason, these Arabic teachers may need samples of lesson plans from similar subjects, such as Indonesian and other foreign languages. Thus, they can better understand lesson plans' substance that must be developed in Arabic teaching and learning. Farida et. Al in their study suggest that teachers should increase their knowledge and skills, particularly things that related to Lesson Plan (RPP) development properly and systematically (Farida dkk., 2018). Related to this issue, Nesari and Heidari in their study propose how important lesson plan is. Therefore, it needs workshop to give information on how to develop a proper lesson plan (Nesari \& Heidari, 2014).

\section{CONCLUSION}

From the description above, it can be concluded teachers' ability, especially Arabic teachers, to prepare good and correct lesson plans represent their professionalism. The Teacher Professional Education Program (Pendidikan Profesi Guru - PPG) allocates 18 hours to help teachers develop the learning materials (lesson plans) because lesson plans have such a functional and strategic position for teaching and learning. This study finds several substantial errors in the lesson plans developed by in-service Arabic PPG participants during teaching practice or Field Experience Activities (Kegiatan Pengalaman Lapangan -- KPL). The errors included (1) ambiguity in the basic competence formulation, (2) GPA formulation that focused more on the process and not competence, (3) invalidity of the assessment instrument, (4) unspecific, non-operational, and unmeasurable formulation of GPA, (5) GPA formulation asynchronous with teaching and learning activities, (6) unclear formulation of teaching and learning activities, (7) unclear measurement of competence, and (8) domain misconceptions in the assessment.

The ambiguity of the lesson plans will affect the learning outcomes and the learning quality. Previous studies showed that the quality of lesson plans was related to learning implementation, classroom management, and effectiveness in improving students' creative thinking. For this reason, it is crucial to provide training that focuses on preparing learning tools such as lesson plans for Arabic subjects in a sustainable manner by emphasizing conceptual and practical understanding.

\section{REFERENCE}

Abidin, Y. (2014). Desain Sistem Pembelajaran dalam Konteks Kurikulum 2013. PT Refika Aditama.

Cicek, V., \& Tok, H. (2014). Effective Use of Lesson Plans to Enhance Education in U.S. and Turkish Kindergarten thru 12th Grade Public School System: A Comparative Study. 10-20.

Cooper, J. M. (1977). Classroom Teaching skills: A Handbook. D.C. Heath and Company. 
Creswell, J. W. (2014). Research design: Qualitative, quantitative, and mixed methods approaches (4th ed). SAGE Publications.

Dorovolomo, J., Phan, H., \& Maebuta, J. (2010). Quality lesson planning and quality delivery: Do they relate? International Journal of Learning, 17, 447-456.

Ellis, C. (2020). Returning Home and Revisioning My Story. Dalam Revision (hlm. 293-339). Routledge. https://doi.org/10.4324/9780429259661-20

Farida, I., Kasim, U., \& Manan, A. (2018). Analysis of Lesson Plans For Teaching Speaking. 14.

Gafur, A. (1982). Desain Instruksional (Suatu Langkah Sistematis Penyusunan Pola Dasar Kegiatan Belajar dan Mengajar). Tiga Serangkai.

Kementerian Pendidikan dan Kebudayaan, K. P. dan K. (2017). Model Pengembangan RPP. Direktorat Pembinaan Sekolah Menengah Atas, Direktorat Jenderal Pendidikan Dasar dan Menengah.

Mahsunah, D., Wahyuni, D., Antono, A., \& Ambarukmi, S. (2012). Kebijakan Pengembangan Profesi Guru. Badan Pengembangan Sumber Daya Manusia Pendidikan dan Kebudayaan dan Penjaminan Mutu Pendidikan.

Marzuqi, M. A. M. (1996). Dalil Al-mu'allim ila Shiyaghati Al-ahdaf At-ta'limiyah Assulukiyah wa Al-maharat At-tadrisyah. Daru Ibn Al-jauzi.

Nesari, A. J., \& Heidari, M. (2014). The Important Role of Lesson Plan on Educational Achievement of Iranian EFL Teachers' Attitudes. 2(5), 8.

Nurgiyantoro, B. (2016). Penilaian Pembelajaran Bahasa Berbasis Kompetensi. BPFE Yogyakarta.

Peraturan Pemerintah No. 74 Tahun 2008 tentang Guru. (2008).

Santrock, J. W. (2010). Educational Psychology (Terjemahan oleh Tri Wibowo, B.S.). Kencana.

Spady, W. G. (1994). Outcome-Based Education: Critical Issues and Answers. America Association of School Administrators.

Sugiyono, Sugiyono. (2018). Metode Penelitian Kombinasi (Mixed Methods). Alfabeta.

Syahrir, S. (2016). Pengembangan Perangkat Pembelajaran Matematika SMP untuk Meningkatkan Kemampuan Berfikir Kreatif. 2(1), 421-434.

Undang-Undang Republik Indonesia Nomor 14 Tahun 2005 tentang Guru dan Dosen. (2005).

Wilkerson, T., \& Scheffler, A. J. (t.t.). Examining an Assumption of Linkage Between Lesson Planning and Implementation. 113(1), 74-79.

\section{COPYRIGHT NOTICE}

Authors retain copyright and grant the journal right of first publication with the work simultaneously licensed under a Creative Commons Attribution 4.0 
International License that allows others to share the work with an acknowledgement of the work's authorship and initial publication in this journal.

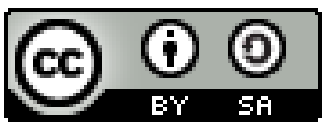

